\title{
PENGARUH PENDEKATAN OPEN-ENDED TERHADAP KEMAMPUAN PEMECAHAN MASALAH MATEMATIS PADA SISWA KELAS VIII SMP HARAPAN STABAT
}

\author{
Rima Ayu Amanda Putri Br. Tarigan ${ }^{1}$, Ice Wirevenska, M.Pd ${ }^{2}$ \\ ${ }^{1}$ Mahasiswa S1 Prodi Pendidikan Matematika \\ ${ }^{2}$ Dosen Prodi Pendidikan Matematika \\ STKIP Budidaya Binjai. Jl. Gaharu Binjai \\ Email : Ice.wr08@gmail.com
}

\begin{abstract}
ABSTRAK
Penelitian ini bertujuan untuk mengetahui pengaruh pendekatan open-ended terhadap kemampauan pemecahan masalah matematis pada siswa kelas VIII SMP Harapan Stabat Tahun Pelajaran 2017/2018 yang pada pokok bahasan Operasi Aljabar. Motode penelitian yang digunakan adalah quasi eksperimen, populasi penelitian ini adalah siswa kelas VIII SMP SMP Harapan Stabat Tahun Pelajaran 2017/2018 yang terdiridari 2 kelas.Sampel dalam penelitian ini diambil secara random, terpilih kelas VIII-2 sebagai kelas Eksperimen 1 dan Kelas VIII-3 sebagai kelas Eksperimen 2.

Untuk memperoleh data yang diperlukan dalam penelitian ini digunakan postes yang berbentuk uralan sebanyak 5 soal untuk tes pemecahan masalah matematika, soal yang dinyatakan valid dan dapat digunakan melihat tingkat kemampuan kreatif dan pemecahan masalah matematika yang diajarkan menggunkan Pendekatan Open-Ended. Data dalam penelitian ini dianalisis dengan analisis statistik-t. Dari analisis data diperoleh tingkat pemecahan masalah matematika siswa untuk kelompok eksperimen sebesar dengan nilai rata-rata 49, simpangan baku sebesar 15 dan varians sebesar 214 dengan total jumlah siswa 30 orang siswa. Dari hasil penelitian diperoleh t hitung sebesar 2,944, dengan rnembandingkan harga ini pada tabel $=1,671$ ternyata $t_{\text {hitung }}>t_{\text {tabel }}$. Jadi dapat disimpulkan bahwa terdapat pengaruh pendekatan Open-Ended terhadap kemampuan pemecahan masalah matematis pada siswa kelas VIII SMP Harapan Stabat tahun pelajaran $2017 / 2018$.
\end{abstract}

Kata Kunci : Pendekatan Open-Ended, Pemecahan Masalah 


\section{PENDAHULUAN}

Matematika merupakan ilmu yang sangat penting yang dinilai dapat memberikan konstribusi positif dalam memacu ilmu pengetahuan. Melalui kurikulum 2013 ini diharapkan sumber optimal mata pelajaran matematika dapat memenuhi harapan dalam penyediaan potensi sumber daya manusia yang handal sehingga memiliki kesanggupan untuk menjawab tantangan era globalisasi serta pesatnya perkembangan ilmu pengetahuan dan teknologi saat ini dan masa yang akan datang. Matematika sebagai salah satu mata pelajaran yang berfungsi mengembangkan kemampuan menghitung, mengukur, dan menggunakan rumus matematika yang digunakan dalam kehidupan sehari-hari. Ini sejalan dengan apa yang dikatakan oleh Wirevenska (2014:1) bahwa kita tidak mungkin bisa hidup normal di tengah masyarakat jika kita tidak memiliki keterampilan dan pengetahuan dasar matematika.
Salah satu karakteristik matematika itu sendiri adalah mempunyai objek yang bersifat abstrak. Sifat abstrak ini menyebabkan banyak siswa mengalami kesulitan dalam belajar matematika. Kondisi ini menyebabkan banyak siswa yang malas mempelajari matematika sehingga banyak materi pembelajaran tidak dikuasai dengan baik kemudian tidak jarang muncul keluhan bahwa matematika hanya membuat siswa bingung dan dianggap sebagai momok yang menakutkan oleh sebagian siswa.

Pada soal tes kemampuan awal saat observasi yang diberikan pada siswa kelas VIII SMP Harapan Stabat terdapat 2 butir soal dalam materi Operasi Bentuk Aljabar. Soal yang diberikan dalam bentuk tes tertulis essay. Soal pertama $\left(4 x^{2}-5 x^{2}-2 x+2-7 x\right)$ dan soal kedua $\left(10 x^{2}+3 x y-5 y^{2}+7 x^{2}-10 x y-2 y^{2}\right.$ ) dan pertanyaan dari kedua soal ini adalah untuk menyederhanaka suku banyak soal tersebut.

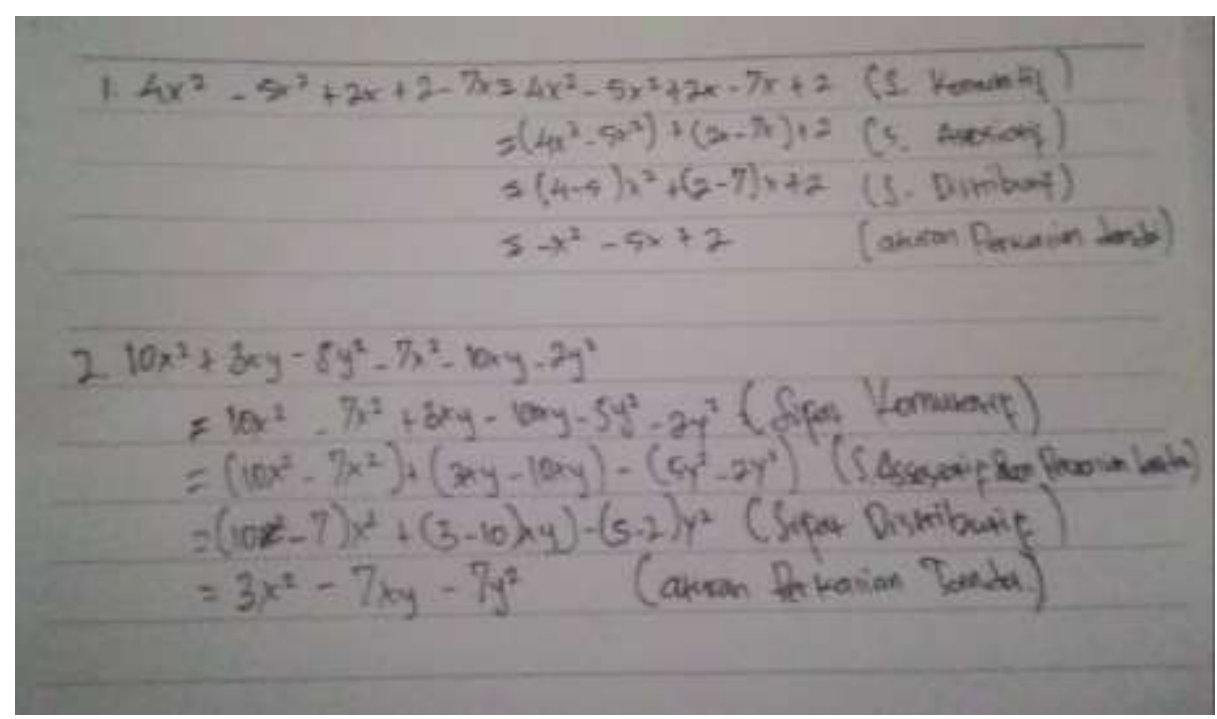




\section{Gambar 1.1 Soal Tes awal}

Dari hasil tes awal, didapatkan hanya dari 39 orang siswa. Hal tersebut menunjukan masih banyak dari siswa yang belum mampu dalam melakukan pemecahan masalah. Seperti yang di ungkapkan oleh G. Polya (1973) bahwa ada beberapa langkah kerja dalam pemecahan masalah, seperti pemahaman pada masalah, membuat rencana pemecahan masalah, melaksanakan rencana penyelesaian, menuju kembali ke solusi yang didapat.

Untuk mengatasi masalah ini, guru perlu menemukan suatu strategi pembelajaran yang dapat membantu siswa dalam menyelesaikan soal - soal berbentuk masalah, menumbuhkan kembali minat siswa dalam belajar. Armanto (dalam Wirevenska, 2018) mengungkapkan "Praktek pembelajaran matematika di sekolah telah terkontaminasi dengan model pembelajaran yang tidak sesuai dengan tujuan pendidikan dasar matematika, dimana guru mengajarkan matematika secara mekanistik (hapalan). Sehingga siswa tidak memahami konsep matematika dan tidak mampu menggunakan dalam menyelesaikan soal cerita".

Salah satu strategi pembelajaran yang dapat membantu siswa memahami dan menyelesaikan suatu materi pembelajaran adalah model pembelajaran Open-Ended yaitu proses pembelajaran didasarkan pada pencarian
5 orang siswa yang diatas KKM (70) dan penemuan melalui berfikir secara sistematis.

Pengetahuan bukanlah sejumlah fakta dari hasil mengingat, akan tetapi hasil dari menemukan sendiri. Model pembelajaran Open-Ended juga merupakan strategi belajar aktif yang mendorong siswa aktif berbagi informasi dan pengetahuan kepada teman yang tidak mampu menyelesaikan soal-soal dan pada sesi akhir guru menyampaikan topik-topik yang penting dari hasil pengerjaan siswa dalam berbagi pengetahuan pada mata pelajaran tersebut.

Dari hasil penelitian Saputri (2018) diperoleh rata-rata tes kemampuan berpikir kreatif kelas eksperimen sebelum dan sesudah pembelajaran adalah 67,56 dan 68,41. Nilai kemampuan berpikir kreatif siswa kelas eksperimen adalah 0,925 sedangkan kelas kontrol 0,396. Nilai kepercayaan diri siswa eksperimen adalah 0,907 sedangkan kelas kontrol 0,396. Maka dapat disimpulkan bahwa terdapat pengaruh pendekatan open-ended terhadap kemampuan berpikir kreatif dan kepercayaan diri pada materi SPLDV di kelas X SMK Putra Anda Binjai.

$$
\text { Selanjutnya Ariani (2017) dalam }
$$
penelitiannya menunjukkan hasil bahwa (1) terdapat perbedaan kemampuan pemecahan masalah yang signifikan antara siswa yang 
mengikuti pembelajaran dengan open-ended problem dan siswa yang mengikuti pembelajaran dengan closed-ended problem, (2) terdapat perbedaan kemampuan pemecahan masalah yang signifikan antara siswa yang mengikuti pembelajaran dengan open-ended problem dan siswa yang mengikuti pembelajaran dengan closed-ended problem setelah kemampuan penalaran abstrak dikendalikan, dan (3) kontribusi kemampuan penalaran abstrak terhadap kemampuan pemecahan masalah sebesar $72 \%$.

Ini sejalan dengan apa yang telah diteliti oleh Saputri, lilies terdapat pengaruh penerapan pendekatan open ended terhadap kreativitas matematika siswa. Pengaruh penerapan pendekatan opend ended terhadap kreativitas matematika siswa SMP Negeri 1 Bahorok.

Berdasarkan penjabaran di atas, maka muncul permasalahan "apakah terdapat pengaruh pendekatan open-ended terhadap kemampuan pemecahan masalah matematis pada siswa kelas VIII SMP Harapan Stabat Tahun Pelajaran 2017/2018 ?”

Tujuan penelitian ini adalah untuk mengetahui pengaruh pendekatan open-ended terhadap kemampuan pemecahan masalah matematis pada siswa kelas VIII SMP Harapan Stabat Tahun Pelajaran 2017/2018.

\section{METODE PENELITIAN}

Populasi dalam penelitian ini adalah seluruh siswa SMP Harapan Stabat yang berjumlah 159 siswa dan dibagi dalam empat kelas.

Teknik sampling yang digunakan adalah Random Sampling Sampel dalam penelitian ini adalah siswa kelas VIII-3 Sebagai kelas Eksperimen yang berjumlah 30 siswa dan kelas VIII-2 sebagai kelas kontrol yang berjumlah 30 siswa.

Jenis penelitian ini adalah quasi experiment karena kondisi siswa tidak dapat dikontrol sepenuhnya seperti : persiapan siswa sebelum belajar disekolah, les tambahan diluar jam sekolah, hubungan siswa dengan orang tua, hubungan siswa dengan lingkungan, dan lain sebagainya. Dalam penelitian ini peneliti, peneliti mengumpulkan data dengan memberikan perlakuan yang berbeda pada dua kelompok sampel penelitian yaitu kelompok sampel untuk kelas eksperimen dan kelompok sampel untuk kelas kontrol.

\section{WAKTU DAN TEMPAT PENELITIAN}

Penelitian ini dilaksanakan di SMP Harapan Stabat Jl. Letjend S. Parman Kec. Stabat pada Tahun Pelajaran 2017/2018. Pelaksanaan penelitian dilaksanakan pada Bulan Juni 2017 sampai dengan selesai smester ganjil.

\section{HASIL DAN PEMBAHASAN}

Dari data yang ada dapat dilihat bahwa hasil uji pemecahan masalah kelas eksperimen yang menggunakan pendekatan open-ended 
memberikan hasil yang lebih baik dibandingkan dengan kelas kontrol yang tidak menggunakan pendekatan open-ended. Dengan demikian dapat dikatakan pembelajaran yang menggunakan pendekatan open-ended bisa meningkatkan pemecahan masalah matematis siswa kelas VIII SMP Harapan Stabat Tahun Pelajaran 2017/2018.

\section{Uji Normalitas Data}

a. Uji Normalitas Data Kelompok Eksperimen 1

Dari hasil perhitungan yang terdapat pada iampiran, berdasarkan tabel nilai kritis Liliefors untuk $\mathrm{n}=40$ dan $\alpha=0,05$ diperoleh $\mathrm{L}_{\text {tabel }}=0,175$, temyata $\mathrm{L}_{\text {hitung }}<$ $\mathrm{L}_{\text {tabel. }}$ Menurut kriteria pengujian hipotesis disimpulkan bahwa Ho ditolak, ini berarti data kemampuan kreatif dan pemecahan masalah kelompok eksperimen berdistribusi normal.

b. Uji Normalitas Data Kelompok Eksperimen 2

c. Dari hasil perhitungan yang terdapat pada lampiran, diperolehL $L_{\text {hitung }}=0,125$, sementara nilai kritis Liliefors untuk $\mathrm{n}=$ 40 dan $\alpha=0,05$ diperoleh 0,175 , ternyata $\mathrm{L}_{\text {hitung }}<\mathrm{L}_{\text {tabe1 }}$. Hal ini berarti data kemampuan kreatif dan pemecahar. rnasalah kelompok eksperimen 2 berdistribusi normal.

\section{Uji Homogenitas Varians Kedua Kelompok}

Untuk menguji homogenitas tingkat kemampuan kreatif dan pemecahan masalah matematika kedua kelompok digunakan statistik F. Dari hasil perhitungan pada lampiran diperoleh $\mathrm{dk}$ penyebut $=40$ serta $\alpha=$ 0,05 diperoleh $F_{\text {tabel }}=1,75$. Berdasarkan tabel distribusi $F$ untuk $F_{\text {hitung }}$ 1,25. Berdasarkan kriteria pengujian homogenitas varians kedua kelompok temyata $\mathrm{F}_{\text {hitung }}<\mathrm{F}_{\text {tabel }}$, maka dapat disimpulkan bahwa kedua kelompok mempunyai varian syang sama.

\section{Pengujian Hipotesis}

Berdasarkan perhitungan pada lampiran diperoleh $\mathrm{L}_{\text {hitung }}=0,125$ sedangkan tabel yang diperoleh dari data distribusi t untuk ternyata a $=0,05 \mathrm{dan} \mathrm{dk}$ penyebut $=40$ diperoleh 1,75 , sehingga berdasarkan kriteria pengujian Ho ditolak. Ini berarti pemecahan masalah matematika siswa yang diajarkan dengan menggunakan pendekatan open-ended lebih baik dibandingkan metode konvensional pada siswa di kelas VIII SMP Harapan Stabat Tahun Pelajaran 2017/2018.

\section{TEMUAN PENELITIAN}

Setelah dilakukan penelitian dengan judul di atas, maka diperoleh beberapa temuan penelitian antara lain:

1. Rata-rata dan Standart deviasi pemecahan masalah matematika siswa yang menggunakan pendekatan open-ended diperoleh $(6,825$ dan 1,26$)$ dan dengan 
menggunakan

pembelajaran

Konvensional nilai rata-rata dan standart deviasi adalah $(5,325$ dan 1,02).

2. Pemecahan masalah matematika siswa dengan menggunakan pembelajaran pendekatan open-ended lebih baik daripada dengan menggunakan pembelajaran Konvensional.

3. Dengan menggunakan uji homogenitas menunjukkan bahwa data berasaldari sampel yang homogen.

4. Harga $t$ hasil penelitian sebesar 2,974 dan haraga $t_{\text {tabel }}$ sebesar 1,668. Dari hasil hipotesis ternyata ada perbedaan yang signifikan dari pemecahan masalah siswa yang menggunakan pendekatan openended dengan menggunakan pembelajaran konvensional.

\section{SIMPULAN}

Berdasarkan hasil analisis data, pengujian hipotesis dan pengamatan maka dapat disimpulkan bahwa terdapat pengaruh yang signifikan terhadap kemampuan pemecahan masalah matematika siswa yang menggunakan pendekatan open-ended dengan metode konvensional. Dari hasil pengujian hipotesis diperoleh $t_{\text {hitung }} 2,944$ dan $t_{\text {tabel }}=1,671$. Hal ini berarti $t_{\text {hitung }}>t_{\text {tabel }}$.

\section{DAFTAR PUSTAKA}

Anas, Sudjiono. Pengantar Evaluasi Pendidikan. Jakarta: PT Raja Grafindo Persada. 2013

Ariani, Desi, M., dkk. Pengaruh Implementasi Open-Ended Problem Dalam Pembelajaran Matematika Terhadap Kemampuan Pemecahan Masalah Dengan Pengendalian Kemampuan Penalaran Abstrak. Universitas Pendidikan Ganesha Singaraja. [pdf : 6 Mei 2017]

Hamzah, Dasar- Dasar Pendidikan. Jakarta : Rineka Cipta. 2006.

Polya, George (1973). How to Solve It - A New Aspect of Mathematical Method (Second edition). New Jersey : Princeton University Press.

Saputri, Lilis. Pengaruh Pendekatan Open Ended Terhadap Kemampuan Berpikir Kreatif dan Kepercayaan Diri pada Materi SPLDV di Kelas X SMK Putra Anda Binjai. Tersedia : http://EJournalSTKIPBudidaya, Jilid 10, Terbitan 2.

Sudjana. Metode Statistik. Bandung : Tarsito. 2005

Sugiyono. Statistika untuk Penelitian. Bndung, Alfabeta. 2012.

Wirevenska, Ice. 2013. Upaya Meningkatkan Kemampuan Penalaran dan Komunikasi Matematik Siswa melalui Pendekatan Matematika Realistik di SMP Karya Bunda. Tesis PPS UNIMED.

Wirevenska, Ice. 2018. Peningkatan Kemampuan Komunikasi Matematik Siswa Melalui Penerapan Model Pembelajaran Problem Posing. Tersedia : http://jurnalMathEducationNusantara 1 (2), 36-44. 
Jurnal Serunai Ilmu Pendidikan Vol.5, No.2, Desember 2019 e-ISSN 2621 - 2676 